\title{
Humanization according to cancer patients with extended hospitalization periods
}

\author{
A humanização segundo pacientes oncológicos com longo período de internação
}

\author{
Natália Tatiani Gonçalves Brito ${ }^{1}$, Rachel de Carvalho ${ }^{2}$
}

\begin{abstract}
Objective: To identify the concept of humanization and raise aspects that contribute towards and that hinder humanization of hospital care, according to the opinion of oncology patients. Methods: This is a descriptive-exploratory survey, with a qualitative-quantitative approach. The sample was made up of 10 patients hospitalized for more than 30 days at the Oncology Unit of Hospital Israelita Albert Einstein, who, after satisfying ethical and legal procedures, were interviewed and answered three questions in reference to humanization in oncology. Results: The factors that contributed more towards humanization were warmth in giving care, friendliness, and smiles, and the factors that hindered it were bad moods, noise, and not being promptly attended. Conclusions: Hospital humanization should be experienced and felt by all those who work at hospital and needs to be reflected in the care offered to the client and his/her family members. These aspects become vital in oncology in order to understand the difficult period the patient is going through during the hospital stay, showing an interest in his/her problems and struggles with an attitude of empathy and cordiality, always acting ethically and with professional responsibility.
\end{abstract}

Keywords: Humanization of assistance; Medical oncology; Oncologic nursing; Hospital care; Patient-centered care

\section{RESUMO}

Objetivo: Identificar o conceito de humanização e levantar os aspectos que contribuem e dificultam a humanização da assistência hospitalar, segundo a opinião de pacientes oncológicos. Métodos: Trata-se de uma pesquisa descritivo-exploratória, prospectiva, com abordagem quali-quantitativa. A amostra constituiu-se de 10 pacientes internados há mais de 30 dias na unidade de Oncologia do Hospital Israelita Albert Einstein, que, depois de cumpridos os devidos procedimentos ético-legais, foram entrevistados e responderam a três perguntas referentes à humanização em oncologia. Resultados: Os fatores que mais contribuíram para a humanização foram carinho, simpatia e sorriso, e os que dificultaram foram mau humor, barulho e não ser prontamente atendido. Conclusões: A humanização hospitalar deve ser vivenciada e sentida por todos os que atuam no hospital e precisa ser refletida na assistência prestada ao cliente e à sua família. Esses aspectos se tornam primordiais na oncologia, para que haja compreensão do momento difícil que o paciente está vivenciando naquela internação, tendo interesse nos seus problemas e nas suas dificuldades, com simpatia e cordialidade no atendimento, atuando com ética e responsabilidade profissional.

Descritores: Humanização da assistência; Oncologia; Enfermagem oncológica; Assistência hospitalar; Assistência centrada no paciente

\section{INTRODUCTION}

Humanizing patient care is a concern in the area of nursing since the days of Florence Nightingale. In Brazil, during the 1970s, Wanda de Aguiar Horta, based on her daily activities with human beings, divulged a model of care that made available to patients a form of treatment that allows self-care, without being separated from nursing accompaniment, leading the professional to recognize the human person as a whole ${ }^{(1)}$. Within this context, there is no more room for merely technical-scientific care disentailed from ethical and humanistic knowledge; thus the importance of discussing the humanization of nursing care. To make patient care humanized is to reveal the values that constitute the human being, as a person, in an ample and comprehensive way ${ }^{(2)}$.

Humanization requires a reflective process about the values and principles that guide professional practice, besides providing treatment and care with dignity, solidarity, and warmth to its primary objective, the fragile being/patient ${ }^{(2)}$. Professional experience has various paths to be taken in the art of nursing, and these possibilities enable professionals to experience,

\footnotetext{
Study carried out at Hospital Israelita Albert Einstein - HIAE, São Paulo (SP), Brazil.

'Master's degree student at Hospital Israelita Albert Einstein - HIAE, São Paulo (SP), Brazil.

${ }^{2} \mathrm{PhD}$, Professor at Faculdade de Enfermagem of Hospital Israelita Albert Einstein - HIAE, São Paulo (SP), Brazil.

Corresponding author: Natália Tatiani Gonçalves Brito - Rua Santa Crescência, 85, apto 13 - Butantã - CEP 05524-020 - São Paulo (SP), Brazil - Tel.: $114524-1757$ - e-mail: nataliatg@einstein.br

Received on Jun 9, 2009 - Accepted on Apr 12, 2010

The authors declare no conflict of interest.
} 
in their daily practice, an extremely technical form of patient care in which there is no room for emotions and personal involvement with the patient $/$ client $^{(3)}$.

Some authors define humanization as an experiential process that permeates all the activities of the institution and of the personnel who work there, not only seeking correct techniques, but also offering the patient the treatment he/she deserves as a human being, within the peculiar circumstances the patient faces while at hospital ${ }^{(4)}$. Others affirm that humanization is centralizing all healthcare policies and resulting actions on man, considering the human being as a whole ${ }^{(5)}$.

By means of Ministry of Health Administrative Ruling No 881 dated 2001, the Secretariat of Healthcare created the National Humanization of Hospital Care Program (PNHAH) with the objective of improving the relations among professionals and clients of healthcare services, of the professionals amongst themselves, and of the hospital with the community, with the intent of modifying the pattern of healthcare given and of furnishing improved quality and efficacy of healthcare services ${ }^{(6)}$. Humanization in Healthcare means to bring back the respect for human life, taking into consideration social, ethical, educational, and psychological circumstances present in every human relationship ${ }^{(6)}$.

In face of the integration of the team, valorization and respect among professionals are fundamental, thus generating a positive response among them. When this integration occurs, the patient feels more confident, safer, and more tranquil as to the hospital stay and the nursing care received, thus diminishing anxiety and affording a more hopeful hospital environment ${ }^{(7)}$.

Patient care is entirely linked to the professional who provides it, and his/her psychological, physical and mental status. In this way, physical fatigue and lack of employees may be disfavorable factors in implementing humanization practices ${ }^{(8)}$.

The patient has the right to have his/her dignity maintained, with respect for needs, values, ethical and moral principles, beliefs, as well as those of the family members; to have relief of pain and suffering with all technological and psychological resources available during the time of treatment, to have his/her privacy respected, as well has to have the conditions and environment necessary to facilitate restoration, maintenance, and improvement of the healthcare offered ${ }^{(9)}$.

In respecting and attending to the needs and rights of the patient, the team that interacts with him/her may more readily attain success in its work, since it is the responsibility of the multiprofessional team to guarantee that these rights be honored ${ }^{(9)}$.

Technological advances are a great conquest, but it is better to associate them to humanization and therapeutic communication, with the intent of obtaining more satisfactory results regarding the patients' wellbeing and science ${ }^{(10)}$.

In this way, healthcare professionals should not allow the disease to continue to be the object of knowledge recognized merely in the scientific realm, separated from the person that carries it and in whom the illness develops ${ }^{(11)}$.

Humanizing nursing care has been a constant challenge, since there is still resistance among the professionals themselves. It is essential to believe that humanized care is always vital for nursing care bedside practice during the patient's hospital stay ${ }^{(12)}$.

There is no doubt that humanization should become the goal in all circles of patient care and specialties that help people, but our focus in the present study is on oncology patients, especially those hospitalized for long periods, generally more than 30 days.

"Patients with malignant tumors require specialized care, since they carry with the stigma of the disease, the uncertainty of the prognosis, fear of death, depression, anxiety, but also the will to live."(13).

In oncology units, it is common to find patients with long hospital stays in which humanization should be present due to the psychological fragility of the patient and his/her family.

The oncology patient needs continued help in his/her daily life, which is essential not only during the time of illness, but during his/her lifetime and hospital stay ${ }^{(14)}$.

Professionals who work in oncology units are daily exposed to conflict-generating situations: frequent losses to death, pressures that impose the traditional responsibility for cure and longevity, constant contact with seriously ill patients and sadness of family members, and bonding with them due to the frequent contact ${ }^{(15)}$.

The proposal of this study was to recognize the importance of humanization in healthcare and to give utmost value to nursing care with dignity to the patients, especially those who are in oncologic therapy and who remain hospitalized, sometimes for several months at a time.

\section{OBJECTIVES}

To identify the concept of humanization and to raise the aspects that contribute towards and that hinder humanization of hospital care according to oncology patients' perception.

\section{METHODS}

\section{Type of study}

This study is descriptive-exploratory and prospective, seeking to observe and describe a phenomenon, investigating its complex nature and the factors to which it 
is related ${ }^{(16)}$. The analysis was qualitative and quantitative. The quantitative analysis was used in raising the aspects that contribute towards and that hinder humanization of hospital care. The qualitative analysis was used to analyze the concept of humanization of hospital care according to the patients, based on the studies of Minayo ${ }^{(17)}$.

\section{Sample and setting}

The study was carried out with patients hospitalized in the Oncology Unit of Hospital Israelita Albert Einstein (HIAE) and the sample was composed of ten patients of both sexes, selected according to the following criteria: adult; having been hospitalized for at least 30 days; agreement to participate in the research by filling out and signing the informed consent form.

\section{Data collection instrument and functionality}

Data were collected after approval of the project by the Research Ethics Committee of HIAE (protocol No 0029.0.028.000-08), as well as after authorization from the administration of the Oncology Unit. The instrument, formulated by the authors, is made up of two parts: data in reference to patient characterization and three questions about the concept of humanization and aspects that hinder and contribute towards its implementation (Appendix 1). The responses were taped and the interviews were entirely transcribed by the researcher, who completed the form according to the answers given by the patients hospitalized for more than 30 days in the Oncology Unit.

\section{Data treatment}

First of all, the literal transcription of the interviews was made in order to have a general understanding of the material collected. Later, the first question (Appendix 1) obtained from the patient's response was qualitatively analyzed, as per Minayo ${ }^{(17)}$. This is a technique for social research analysis in the field of health that emphasizes health-illness as a phenomenon that breaks through biological contours and recognizes the permanent link between body and mind. Its central concern is to reestablish a connection between social sciences, philosophy, and linguistics in order to discipline the analysis of texts and research interviews. According to Minayo $^{(17)}$, the following steps were carried out: ordering of data (including rereading the material), organization of reports as per similarity of meaning and classification of data, and formation of analytical categories.

The third and fourth questions (Appendix 1) were quantitatively analyzed, and data was presented in absolute numbers on charts.

\section{RESULTS}

The data were analyzed as per the questions made to the interviewees.

Characterization of the ten patients who made up the sample may be seen on Charts 1 and 2 .

Chart 1. Characterization of sample patients per age, gender and length of hospital stay $(n=10)$, São Paulo, 2008

\begin{tabular}{|lccc|}
\hline Patient & Age & Gender & $\begin{array}{c}\text { Length of hospital stay* } \\
\text { (days) }\end{array}$ \\
\hline 1 & 43 & Male & 40 \\
2 & 23 & Female & 32 \\
3 & 24 & Female & 30 \\
4 & 62 & Male & 43 \\
5 & 42 & Female & 37 \\
6 & 62 & Male & 39 \\
7 & 80 & Male & 33 \\
8 & 57 & Male & 30 \\
9 & 18 & Female & 33 \\
10 & 47 & Male & 32 \\
\hline
\end{tabular}

*Length of hospital stay represents the period between date of admission and the date of data collection.

Chart 2. Characterization of sample patients per diagnosis and treatment $(n=10)$, São Paulo, 2008

\begin{tabular}{|lll|}
\hline Patient & Diagnosis & Treatment \\
\hline 1 & $\begin{array}{l}\text { Breast cancer (left breast) }+ \\
\text { metastasis in the central nervous } \\
\text { system (CNS) + lung cancer }\end{array}$ & Chemotherapy + radiation therapy \\
2 & Breast cancer + sepsis & Clinical \\
3 & Acute lymphoid leukemia (ALL) & Chemotherapy \\
4 & Non-Hodgkin lymphoma (NHL) + & Chemotherapy \\
& astenia + fever & Clinical \\
6 & Lung cancer & Clinical \\
6 & NHL + astenia + fever & Clinical \\
8 & Primary NHL + metastasis CNS & Clinical \\
9 & Esophageal cancer & Clinical \\
10 & Liver cancer & Clinical \\
\hline
\end{tabular}

Most patients were males (6 or $60 \%$ ) and four of them $(40 \%)$ were females. Age ranged from 18 to 80 years, with a mean age of 46 years; the mean time of hospitalization at the moment of data collection was 35 days. Of the 10 patients interviewed, 7 (70\%) were undergoing clinical treatment, $2(20 \%)$ were receiving chemotherapy, and one $(10 \%)$ was receiving chemotherapy and radiation therapy. All patients (10 or $100 \%$ ) had been previously admitted to the institution.

The first question was analyzed qualitatively, according to Minayo ${ }^{(17)}$, as per similarities of meanings and use of analytical categories, separated into Technical Aspects, Sentimental Aspects, Personal Aspects, and Interaction with the Professional (Chart 3). 
Chart 3. Concepts of humanization of care divided into analytical categories, according to oncology patients (n = 10), São Paulo, 2008

\begin{tabular}{|c|c|c|c|c|}
\hline Patient & Technical aspects & Sentimental aspects & Personal characteristics & Interaction with professionals \\
\hline 1 & Care & - & Sense of humor & $\begin{array}{l}\text { To feel as part of the process } \\
\text { To talk to the patient }\end{array}$ \\
\hline 2 & Care and ethics & - & - & $\begin{array}{l}\text { Closeness } \\
\text { Bond }\end{array}$ \\
\hline 3 & - & Affection & Education & $\begin{array}{l}\text { To treat the patient as a human being } \\
\text { To be on his/her side }\end{array}$ \\
\hline 4 & - & - & $\begin{array}{l}\text { Sense of humor } \\
\text { No personal problems }\end{array}$ & $\begin{array}{l}\text { To give support } \\
\text { Collaboration }\end{array}$ \\
\hline 5 & $\begin{array}{l}\text { Competence } \\
\text { Dedication }\end{array}$ & Affection & $\begin{array}{c}\text { Sympathy } \\
\text { Education } \\
\text { No personal problems }\end{array}$ & $\begin{array}{l}\text { To give support } \\
\text { To treat the patient as a human being }\end{array}$ \\
\hline 6 & Dedication & - & Understanding & To feel as part of the process \\
\hline 7 & - & - & Respect & To treat the patient as a human being \\
\hline 8 & $\begin{array}{c}\text { Care } \\
\text { Dedication }\end{array}$ & $\begin{array}{l}\text { Affection } \\
\text { Love }\end{array}$ & - & - \\
\hline 9 & $\begin{array}{l}\text { Quality of service } \\
\text { Dedication }\end{array}$ & - & Responsibility & \\
\hline 10 & $\begin{array}{l}\text { Individualization } \\
\text { Customization }\end{array}$ & - & Respect & Valorization \\
\hline
\end{tabular}

Chart 4. Aspects that contribute towards hospital humanization, according to oncology patients ( $\mathrm{n}=10$ ), São Paulo, 2008

\begin{tabular}{|lc|}
\hline Aspects that facilitate humanization & Number of answers* \\
\hline Affection & 5 \\
Sympathy/smiles & 5 \\
Understanding & 3 \\
Interest & 2 \\
Privacy for patient & 2 \\
Emergency care & 2 \\
Respect & 2 \\
Getting close to the patient & 1 \\
Keeping the same professionals & 1 \\
Providing support & 1 \\
Quality in care & 1 \\
Performing volunteer work & 1 \\
Responsibility & 1 \\
Voice tone & 1 \\
Differentiated treatment & 1 \\
Bond & 1 \\
Total & 30 \\
\hline
\end{tabular}

*The number of answers exceeds the number of subjects, since each interviewee could mention as many factors as they deemed necessary.

The third and fourth questions were analyzed quantitatively and are presented on Charts 4 and 5, according to the aspects that, in the opinion of the patients, contributed towards and hindered hospital humanization in oncology.

\section{DISCUSSION}

For the qualitative analysis, comments referring to the analytical categories are presented, including actual quotes from the patients themselves.
Chart 5. Aspects that hinder hospital humanization, according to oncology patients $(n=10)$, São Paulo, 2008

\begin{tabular}{|lc|}
\hline Aspects that hinder humanization & Number of answers* \\
\hline Bad humor & 5 \\
Noise & 4 \\
Not being seen & 4 \\
Lack of respect & 3 \\
Interruptions during sleep & 3 \\
Change of professionals & 3 \\
Personal characteristics & 1 \\
Difficulty in relating to others & 1 \\
Excessive visits to the room & 1 \\
Lack of collaboration of the patient & 1 \\
Lack of contact & 1 \\
Fear to get close to the patient & 1 \\
Not looking into the eyes & 1 \\
To be badly treated & 1 \\
Total & 29 \\
*The number of answers exceeds the number of subjects, since each interviewee could mention as many factors \\
as they deemed necessary.
\end{tabular}

We note that interaction is the most important aspect for patients when asked about the concept of humanization, since $80 \%$ of those interviewed reported that, for them, humanization depends on interaction with the professional, so that the professional is able to make the patient feel that he/she is a part of the process.

Personal characteristics are equally important, since they were also cited by $80 \%$ of those interviewed who consider humanization as the manner in which they are treated by the professionals.

The technical aspects are relevant for $70 \%$ of the study patients, which correlates humanization with the 
work characteristics of the professionals. On the other hand, sentimental aspects were mentioned by $30 \%$ of those interviewed.

The interaction between the patient and the nursing team is fundamental for establishing an affective bond in order to promote care of the other person with quality, since by active listening on the part of the care giver, there is understanding and valuation of the ideas of the patient, and the confidence gained enables becoming conscious of his/her emotions, making patient care appropriate and improving compliance with treatment ${ }^{(12-13)}$. From the perspective of the workers, some get involved and give themselves in forming stronger bonds, committing themselves and assuming responsibility for actions intended to improve nursing and patient care offered by the healthcare institution. Being aware of the characteristics of the person under treatment increases the possibility of a professional/ client bond, an aspect that contributes to and is essential for offering humanized patient care ${ }^{(18)}$.

According to the patients interviewed, to have the support and strength at this time of difficulty in their lives may become a distinguishing aspect of the treatment, besides minimizing the negativism of day-today life at hospital.

Personal characteristics may have an influence since when care is understood as an act, an action, or an attitude devoid of judgments and prejudices, ethical solidarity is translated by respect for the patient and his/her individuality, intimacy, and his/her space with beliefs and values. It is widely known that nursing care constitutes the essence of nursing and extends to each patient. Thus, it is up to the nurse to recognize the peculiarities of each patient he/she cares for, and to adapt the nursing care given in order to best meet individual needs ${ }^{(4)}$.

Within this context, to be solidary means to demonstrate sensitivity and flexibility, to work with and on the differences, to be available to another, with responsibility for one's actions. In this way, the human being should be respected and treated with equality, having his/her rights preserved, regardless of the pathology ${ }^{(18)}$.

Patients report that they feel it when the professional is involving his/her personal problems with daily patient care, by demonstrations in the nurse's sense of humor and compassion, and many times fail to understand a patient's moment of pain.

To humanize is also to consider the patient as an emotional, suffering being, who suffers psychologically and is saddened, who creates fantasies, feels fear, and should be cared for by well-prepared professionals ${ }^{(14)}$.

As to the technical aspects, the practice of humanization should be observed on an ongoing basis.
Ethical behavior should be the principle of life of the organization; the current longing of society for ethical treatment is evident, since it is a part of the needs of the contemporary man. Nowadays, the client knows his/her rights and always desires to defend them, involving a demand for improvement in the quality of services offered, and more attention given to problems and competency in acts, since they directly involve the patient's health ${ }^{(19)}$.

The healthcare professional should amplify the focus of care so as to involve sentimental aspects as well as the desires and preferences of the patients, in order to restore fundamental principles and values for a harmonious interaction between the patient, the family, and the nursing team, offering warmth, love, and dedication $^{(2)}$.

According to the authors ${ }^{(20)}$, the aspects that facilitate humanization include satisfying the deepest desires of patients to be understood in their needs by means of care, and understanding is a fundamental step that requires commitment on the part of the professional in attempting to meet these needs; availability is also necessary for this to happen. Openness to true giving of care certainly will contribute to humanization of nursing care.

The verbal and corporal perspective of staying by the patient's side, offering support, touching the patient, treating him/her with a smile and dedication are some of the primary aspects of humanization. Touching, listening with empathy, and other practices that make up integral nursing care may be fundamental resources for the process of cure ${ }^{(20)}$.

The negative aspects cited most frequently by the patients include bad moods, delay in answering the patient's request for help, noise at the nursing station, and interruption of sleep, which for them is vital for recovery.

The professional may experience a degree of fatigue, especially at the end of the work shift, and this may be one of the reasons for bad mood, but it should not become a plausible justification. The delay in answering a patient's call may be related to innumerable factors such as priority in treating other patients, schedules for procedures such as distributing medication and providing hygiene care, besides the accumulation of activities during certain periods. Many times, the professional begins to perform tasks mechanically, leaving aside feelings and needs of the patient ${ }^{(20)}$ and not respecting the individual's moments, such as of sleep and pain, which makes the relationship more difficult.

One of the patients interviewed reported that if there is no collaboration on the part of the patient, humanization may also be impaired. We found this comment interesting, since it shows that the other side 
of the interaction is also fundamental for a healthy relationship and good interaction on the part of all those involved. It is indispensable for the patient to have this understanding.

As to the nursing professional, to assume a humanized behavior implies considering the human being as an individual who belongs to society, with knowledge, spirituality, culture, and feelings. This means to treat a person under one's care with respect and with ethical values, in order to guarantee his/her individuality and condition of a social being ${ }^{(4)}$.

During the collection of data, there was difficulty in including patients in the sample according to the criteria established in the study. As to the time of hospital stay, many clients had already been discharged from the hospital and others were terminal patients, with whom it was impossible to conduct an interview, while others had passed away.

After obtaining ten patients for the sample and analyzing the data collected, we verified that hospital humanization is necessary, in the sense of having an understanding of the difficult phase the patient is experiencing during that hospitalization, respecting his/her private moments, demonstrating interest in his/her problems and struggles, giving assistance with friendliness and cordiality, based on ethics and professional responsibility, since to humanize is to restore respect for human life, reinstating his/her values and offering quality care to the patient and his/her family, especially during a long hospital stay. There should also be availability, especially during a long hospital stay, and a disposition for giving care, without involvement of personal problems, respecting the patient's condition and avoiding excessive noise at the nursing station.

Humanization for oncology patients depends on interaction with the professional, so that the nurse is able to make the patient feel a part of the process by involvement of aspects of technical and sentimental nature, and personal characteristics.

\section{CONCLUSIONS}

According to the interviewed patients, the main factors that facilitate humanization of nursing care involved warmth, friendliness, understanding of the phase the patient is going through, respect, and quality of care given. The most frequently cited negative factors were bad mood of professionals, interruption of the patient's sleep, and excessive nursing visits to the patient's room.
It is mandatory that professionals go through a process of reflection, solidarity and humanitarianism that values the human being in all aspects that surround him/her.

\section{REFERENCES}

1. Leite RS, Nunes CV, Beltrame I. Humanização hospitalar: análise da literatura sobre atuação de enfermagem [tese]. São Paulo: Universidade de São Paulo, Escola de Enfermagem; 2002.

2. Pessini L, Bertachini L. Humanização e cuidados paliativos. São Paulo: Loyola; 2004.

3. Ribeiro RC, Carandina DM, Farah OG, Fugita RM. Tecnologia e humanização: visão de enfermeiros de CC e UTI. Rev SOBECC. 1999;4(3):15-9.

4. Carvalho R, Paula MF, Moraes MW. Tecnologia e humanização em centro cirúrgico. In: Carvalho R, Bianchi ER, organizadores. Enfermagem em centro cirúrgico e recuperação. Barueri: Manole; 2007. p. 316-34.

5. Whitis G. Simulation in teaching clinical nursing. J Nurs Educ. 1985;24(4): $161-3$

6. Brasil. Ministério da Saúde. Secretaria de Assistência à Saúde. Programa Nacional de Humanização da Assistência Hospitalar. Brasília (DF): Ministério da Saúde; 2001. [Série C. Projetos, Programas e Relatórios, n. 20].

7. Gelain IJ. A humanização do hospital. Rev Paul Hosp. 1990;16(1):3-7.

8. A arte como ferramenta na humanização hospitalar. Rev Coren-SP. 2002;42:711.

9. Martins JJ, Faria EM. A (re)organização do trabalho da enfermagem em UTI través de uma nova proposta assistencial. Texto \& Contexto Enferm. 2000;9(2):388-401.

10. Fortes PA, Martins CL. A ética, a humanização e a saúde da família. Rev Bras Enferm. 2000;53(n. esp):31-3.

11. Backes DS, Lunardi VL, Lunardi Filho WD. A humanização hospitalar como expressão da ética. Rev Latino-am Enferm. 2006;14(1):132-5.

12. Campos OR. Reflexões sobre o conceito de humanização em saúde. Saúde Debate. 2003;27(64):123-30.

13. Leite RC. Assistência humanizada de enfermagem ao paciente oncológico. In: Mohallen $A G$, Rodrigues $A B$, organizadores. Enfermagem oncológica. Barueri (SP): Manole; 2007. p. 187-93.

14. Volpato FS, Santos GR. Pacientes oncológicos: um olhar sobre as dificuldades vivenciadas pelos familiares cuidadores. Imaginário [periódico na Internet]. 2007 Jun [citado 2010 May 27]:13(14); [cerca de 33p]. Disponível em: http:// pepsic.bvs-psi.org.br/pdf/ima/v13n14/v13n14a24.pdf

15. Ferreira AL. A difícil convivência com o câncer: um estudo das emoções na enfermagem oncológica. Rev Esc Enferm USP. 1996;30(2):229-53.

16. Dias C. Grupo focal: técnica de coleta de dados em pesquisas qualitativas. Informação \& Sociedade: estudos. 2000;10(2):141-58.

17. Minayo MC. 0 desafio do conhecimento. 6a ed. São Paulo: HUCITEC; 2000.

18. Gazzotti AA. Educação: carinho e trabalho. Petrópolis: Vozes; 1999.

19. Eco U. Quando o outro entra em cena, nasce a ética. Reflexão: diálogo sobre a ética [Internet] [citado 2002 Fev 8]. Disponível em: http://www.ethos.org.br/ docs/conceitos_praticas/publicacoes/reflexao/index.shtml.

20. Hoga LA. A dimensão subjetiva do profissional na humanização da assistência à saúde: uma reflexão. Rev Esc Enferm USP. 2004;38(1):13-20. 
Appendix 1. Data collection instrument

Form: Humanization according to oncology patients with long hospital stay periods

I) Characterization of the patient:

Age:

Diagnosis:

Treatment
( ) clinical
( ) surgical
( ) radiation therapy
( ) chemotherapy

( ) bone marrow transplantation

Date admitted:

Length of hospital stay:

Prior hospitalization at the Unit:

Date of data collection:

II) Humanization for the oncology patient:

1. In your opinion, what is humanization of hospital care?

2. Cite 3 (three) aspects that contribute towards humanization in hospital care.

3. Cite 3 (three) aspects that hinder humanization of hospital care. 